\title{
RANCANG BANGUN ALAT PEMARUT DAN PEMERAS SANTAN KELAPA DENGAN MENGGUNAKAN 1 MOTOR PENGGERAK UNTUK MENINGKATKAN EFEKTIFITAS
}

\begin{abstract}
Abstrak
Kata Kunci:

Antropometri;

ergonomis; kelapa

perancangan; pemeras;

pemarut.

Pengolahan bahan baku makanan masih banyak yang menggunakan mesin pemarut kelapa dan pemeras kelapa yang terpisah, hal ini menyebabkan proses yang cukup lama dalam proses produksi. Pada dasarnya mesin pemarut lama yang beredar di pasaran hanya bisa digunakan untuk memarut saja. Sedangkan alat peras masih menggunakan saringan kelapa yang diperas menggunakan tangan. Penelitian ini dimulai dengan survei ke pasar tradisional dan pengusaha jasa pemarut kelapa yang ada di sekitar Semarang guna mengetahui kerja alat yang ada di pasaran dan mengetahui keinginan calon pengguna. Dari survei tersebut akan diperoleh data costumer need yang akan dipakai sebagai acuan untuk pengembangan konsep pembuatan alat. Data antropometri diperlukan untuk merancang dimensi alat, sehingga alat yang dibuat akan ergonomis dan nyaman digunakan oleh operator. Alat pemarut dan pemeras santan kelapa yang dirancang ini memiliki dimensi ketinggian $105 \mathrm{~cm}$ dan lebar $74 \mathrm{~cm}$ memiliki bagain- bagian antara lain : kerangka, pemarut, ulir pemeras, motor penggerak, gear box, tempat air, dan pulley/roda.
\end{abstract}

\author{
Akhmad Syakhroni ${ }^{1}$, Sukarno Budi Utomo ${ }^{2}$ \\ ${ }^{1,2}$ Program Studi Teknik Industri, Universitas Islam Sultan Agung
syakhroni@unissula.ac.id 1, pakdhekarno@yahoo.com \\ ${ }^{2}$ Program Studi Teknik Industri, Universitas Islam Sultan Agu
syakhroni@unissula.ac.id 1, pakdhekarno@yahoo.com
}

\section{Abstract}

\section{Keywords:}

Anthropometry; ergonomics; coconut ; design; squeezer; grater.
There are many of food processing of raw materials are still using a separate tools of coconut grater and squeezer, which causes a long production process. Basically the grater machines on the market only can be used to scrape away the coconut meat. While the tool for extracting the coconut milk is still using coconut sieve and squeezed by hand. The Research initiated with a survey into traditional markets and entrepreneurs of coconut grater services around Semarang. The survey aimed to identify the tools used in the market and the needs of potential users. The survey obtained data of customer's need that will be used as a reference for developing the concept of making tools. Anthropometric data needed to design the dimensions of the tool, with the purpose of the tool made will be ergonomics and comfortable to be used by the operator. Grater and Squeezer of Coconut Milk Tool which designed has dimensions of $105 \mathrm{~cm}$ height and $74 \mathrm{~cm}$ width. It has parts: the framework, grater, bleeder screw, motor, gear box, water container, and a pulley / wheel.

\footnotetext{
$\bowtie$ Alamat korespondensi :

E-mail :

ISSN : $2087-1627$
} 


\section{Latar Belakang}

Dunia industri khususnya industri rumahan (home industry) pembuatan makanan, ataupun tempat pemarutan kelapa, pengolahan bahan baku makanan masih banyak yang menggunakan mesin pemarut kelapa dan pemeras kelapa yang terpisah, hal ini menyebabkan proses yang cukup lama dalam proses produksi.

Pada dasarnya mesin pemarut lama yang beredar di pasaran hanya bisa digunakan untuk memarut saja, sedangkan alat peras masih menggunakan saringan kelapa yang diperas menggunakan tangan bisa dilihat pada gambar 1 .

Dengan berkembangnya zaman maka terciptalah mesin pemarut dan mesin pemeras kelapa. Mesin ini mempunyai peran penting dalam keberlangsungan proses produksi. Selama ini mesin pemarut sekaligus pemeras yang telah beredar dikalangan masyarakat hanya mempunyai parut dan peras tunggal, sehingga untuk membuat produk memerlukan waktu yang cukup lama karna terbatasnya fungsi mesin yang ada. Selain itu untuk efisiensi proses produksi para pengusaha perlu melakukan penambahan jumlah mesin dan jumlah operator karena selama ini mesin pemarut di operasikan 1 operator, begitu juga dengan pemerasan.

Dari hal tersebut di atas, kami ingin membuat terobosan dengan merancang dan membuat mesin pemarut yang bisa digunakan sekaligus melakukan proses pemerasam dengan satu motor penggerak, tujuan utama dari mesin ini adalah dapat meningkatkan efisiensi proses produksi karena mempunyai dua fungsi dan lebih hemat biaya karena menggunakan satu penggerak dan satu operator, mesin ini juga mempunyai keunggulan bisa melaksanakan dua oprasi sekligus dalam satu mesin sehingga dapat melakukan pemrosesan bahan baku produksi secara cepat.

\section{Metode}

Berikut adalah diagram alir metode penelitain yang dilakukan :

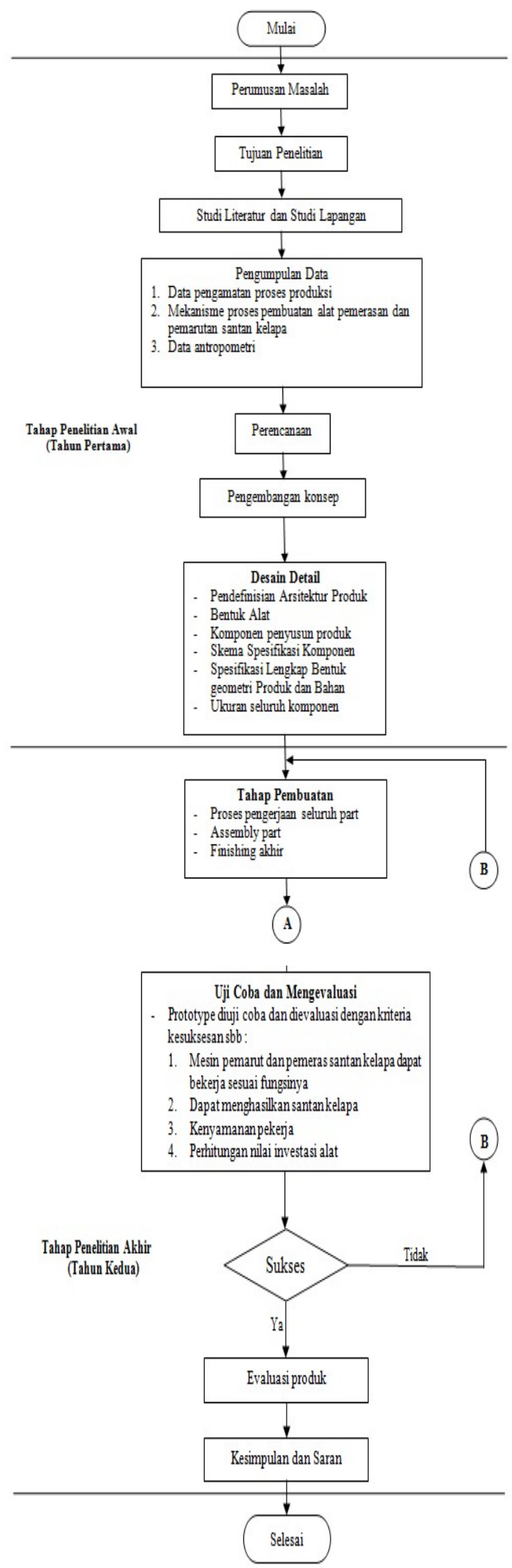




\section{Hasil dan Pembahasan}

Penilitian ini kami mulai dengan melakukan survey di beberapa pasar yang ada di Semarang dan masyarakat umum pelaku industri rumahan yang bergerak di bidang pemarutan kelapa. Adapun datadata yang dikumpulkan dalam penelitian ini adalah data mengenai gambaran umum mesin pemarut dan pemeras kelapa, antara lain data mekanisme proses pemarutan dan pemerasan kelapa untuk menjadi santan kelapa, data antropometri, penjabaran pembuatan alat yang meliputi customer need, perencanaan, pengembangan konsep, system level desain, komponen penyusunan produk dan skema penyusun produk, pengolahan data, desain detail.

\subsection{Data Hasil Kuesioner Customer Need}

Data kuesioner customer need ini merupakan dasar untuk melakukan perancangan mesin pemarut dan pemeras. Data diambil dari beberapa beberapa pasar yang ada di Semarang dan masyarakat umum pelaku industri rumahan yang bergerak di bidang pemarutan kelapa dan melakukan wawancara langsung kepada responden terhadap proses pemarutan yang dilakukan oleh pekerja.

Berikut hasil perolehan data dari kuesioner tersebut:

a. Alat yang mempunyai desain yang ergonomis.

b. Alat yang dikembangkan sistemnya secara otomatisasi tidak secara manual.

c. Alat pemarutnya sekaligus sebagai pemeras jadi lebih efektif dan efisien.

d. Alat menggunakan bahan yang higienis dan steril.

e. Alat mudah dalam pengoperasiannya dan perawatannya.

f. Alat dapat melakukan proses pemarutan dan pemerasan dengan cepat.

g. Alat yang hemat listrik atau bahan bakar.

h. Alat yang bisa secara otomatis memisahkan antara santan kelapa dan ampas.

i. Alat yang bisa mengahasilkan parutan dan santan dengan kualitas yang baik.

j. Alat yang dapat melakukan pengoperasian dengan kapasitas yang besar.

\subsection{Pengolahan Data Anthropometri}

Hasil Pengolahan persentil data anthropometri ditunjukkan pada Tabel 1.

\subsection{Perancangan Desain}

Perancangan dalam pembuatan mesin pemarut dan pemeras dilakukan bertujuan untuk melakukan proses pembuatan santan kelapa guna meningkatkan produktifitas. Diharapkan dengan adanya perancangan alat yang baru bisa membantu mengatasi permasalahan yang ada sekarang.
Konsep yang akan dipilih berdasarkan diskusi mengenai ketepatan dengan customer need. Konsep yang terpilih tersebut kemudian akan diuji dengan menggunakan prototype. Pemenuhan kebutuhan pelanggan dapat dilihat pada Tabel 2.

\subsection{Pengembangan Konsep}

Pengembangan konsep pada penelitian ini mempunyai gagasan pada sebuah perancangan mesin pemarut dan pemeras santan kelapa, bahwa alat yang sudah beredar di masyarakat relatif antara proses pemarutan kelapa dan pemerasan santan kelapa dilakukan secara terpisah, membutuhkan membutuhkan banyak waktu dalam proses pembuatan santan kelapa. Melihat keluhan para pelaku usaha mikro yang bergerak di bidang pemarutan kelapa saat ini maka perancangan dalam pengembangan mesin pemarut dan pemeras dilakukan bertujuan untuk dapat meringankan para pengusaha dalam meningkatkan produktifitas sekaligus menghemat waktu pembuatan santan kelapa. Oleh karena itu konsep pengembangan dari alat ini adalah :

a. Alat yang dikembangkan selain bisa melakukan proses pemarutan kelapa juga bisa melakukan pemerasan santan kelapa sekaligus, dengan menggunakan 1 motor penggerak saja.

b. Alat yang dibuat mempertimbangkan faktor ergonomi dengan perhitungan data antropometri tubuh manusia sehingga alat yang dipakai nyaman.

c. Alat yang dibuat untuk proses pemerasaanya tidak manual lagi, bisa memisahkan antara santan dan ampas kelapa dengan kualitas yang baik.

d. Alat yang dibuat memenuhi aspek kebersihan, hiegenis, steril, mudah dalam pengoperasian dan perawatannya, hemat energi, lebih efektif dan efisien dibandingkan dengan perelatan sebelumnya.

\subsection{Desain Detail}

Komponen penyusun produk untuk Alat pemarut dan pemeras santan kelapa ini, terdiri dari komponen-komponen yang dirangkai menjadi satu sehingga menjadi sebuah alat pemarut sekaligus pemeras santan kelapa dapat dioperasikan. Masingmasing komponen penyusun produk beserta fungsinya, yaitu :

a. Rangka sebagai tempat dan dudukan untuk pemasangan dinamo, gear box, tempat air, pemarut kelapa, pemeras santan kelapa dan roda $\mathrm{v}$ belt.

b. Dinamo sebagai penggerak utama alat pemeras dan pemarut kelapa. Dinamo akan menggerakan $\mathrm{v}$ belt yang terhubung dengan alat pemarut dan pengerok kelapa. Dinamo akan menggerakan $\mathrm{v}$ belt yang terhubung 
dengan gear box yang terhubung dengan alat pemeras kelapa.

c. Gear box sebagai alat khusus yang diperlukan untuk menyesuaikan daya atau torsi (momen/daya) dari motor yang berputar, dan gearbox juga adalah alat pengubah daya dari motor yang berputar menjadi tenaga yang lebih besar untuk memeras kelapa menjadi santan.

d. Tempat air sebagai tempat air yang disediakan untuk mengaliri kelapa saat diperas, hal ini untuk memudahkan kelapa diperas.

e. Pemarut kelapa sebagai alat pemarut kelapa yang masih besar/utuh untuk diparut menjadi kecil-kecil.

f. Pemeras santan kelapa, kelapa yang sudah diparut akan dipasukan ke alat pemeras kelapa untuk diambil santanya.

g. V belt dan roda sebagai penghubung antara dinamo penggerak dengan gearbox, gearbox ke pemarut dan gearbox ke pengerok kelapa.

h. Pengerok kelapa sebagai alat pengerok kelapa yang masih utuh tapi sudah dibelah menjadi dua.

\subsection{Skema Penyusun Produk}

Skema penyusun produk untuk alat yang dibuat pada Gambar 1 .

a. Proses pemasangan atau perakitan dari dinamo, gear box, tempat air, alat pemeras, alat pemarut dan roda dipasang ke kerangka. Untuk v belt dipasang ke roda dan alat pengerok dipasang ke alat pemarut jadi satu, baru kemudian dirangkai ke kerangka.

b. Untuk proses fungsi kerja dinamo menggerakan roda yang terhubung ke $\mathrm{v}$ belt yang akan menggerakan pemarut dan pengerok. Dinamo jga terhubung ke gear box yang akan menggerakan alat pemeras. Air dikendalikan oleh operator akan dialirkan ke alat pemeras bersama kelapa.

\subsection{Spesifikasi Lengkap Bentuk Geometri Produk}

Tahap ini meliputi spesifikasi lengkap mengenai bentuk geometri produk dan komponennya, bahan yang digunakan, serta ukuran dari seluruh part penyusun komponen dan produknya, termasuk pula proses pengerjaan.

\section{Kesimpulan}

Alat pemarut kelapa yang ada di pasaran, hanya bisa melakukan proses pemarutan kelapa saja, sedangkan proses pemerasan untuk menghasilkan santan kelapa, dilakukan secara terpisah dengan menggunakan tangan. Agar lebih efektif maka perlu dilakukan perancangan dan pembuatan mesin yang bisa melakukan kedua proses tersebut dengan cukup menggunakan 1 motor penggerak.

Alat pemarut dan pemeras santan kelapa ini didesain dengan mendasarkan pada data antropometri tubuh manusia serta keinginan konsumen, sehingga alat yang dibuat akan ergonomin dan nyaman digunakan oleh operator.

Alat yang didesain memiliki ketinggian $105 \mathrm{~cm}$ dan lebar $74 \mathrm{~cm}$ ini memiliki bagain- bagian antara lain : kerangka, pemarut, ulir pemeras, motor penggerak, gear box, tempat air, dan pulley/ roda

\section{Daftar Pustaka:}

[1] Alfauzi, A.S, Rofarsyam, 2005, "Mesin Pemeras Kelapa Parut Menjadi Santan Sistem Ulir Tekan Penggerak Motor Listrik 1 HP”, Jurnal TEKNOIN Vol. 10, No. 4, Desember 2005, ISSN : 0853-8697, hal. 249-256

[2] Arum Soesanti, Sunardi Tjandra, 2010, "Redesain Mesin Pemarut Kelapa Mini untuk Mereduksi Biaya Material dan Biaya Manufaktur, Proseeding Seminar on Aplpication and Research in Industrila Technology , SMART 2010, ISBN 978-602-97567-4-6

[3] Imam Ghazali, Manggara Tambunan, Nazlina, 2013, "Perancangan Alat Pemeras Kelapa Parut Menjadi Santan dengan Cara Pengepresan Manual yang Ergonomis", Jurnal Teknik Industri FT USU, Vol. 2, No. 2, Juni 2013, hal 19-27, Medan

[4] Junaidi, Eka Sunitra, 2008, "Rancang Bangun Mesin Pemeras Santan dengan Metode Kombinasi Pemarutan dan Pemerasan dengan Sistem Screw", Jurnal POLYREKAYASA Vol. 4, No. 1, Oktober 2008, ISSN : 1858-3709, hal 36-41

[5] Purnomo Hari., 2004, "Pengantar Teknik Industri”, Graha ilmu,Yogyakarta

[6] Ramdhoni A., 2009, "Pengaruh Pasteurisasi dan Lama Simpan Terhadap Sifat Fisik, Kimia Mikrobiologis dan Organik ”,Jakarta

[7] Santoso Gempur., 2004, “ Ergonomi Manusia, Pralatan dan Lingkungan", Prestasi pustaka, Sidoarjo

[8] Suma'murPK.,2004, “ Ergonomi Untuk Produktivitas Kerja”, Yayasan Swabhama kerja,Jakarta.

[9] Trioyono, Haryanto, dan Sudarya, 2002, Rancang Bangun Mesin Press Kopra Tipe Ulir Skala Kecil.Prosiding, Seminar Nasional Memacu Agro Industri Berbasis Komoditi Unggulan Daerah

[10] UlrichEppinger.,2001,"Perancangan Pengembangan Produk", salemba teknika, Jakarta. 


\section{Lampiran}

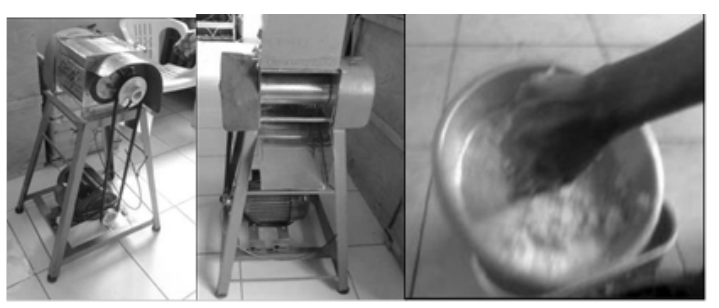

Gambar 1. Mesin Pemarut Kelapa dan Peras Tangan

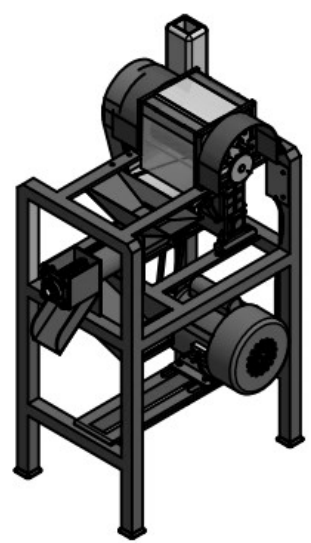

Gambar 1. Desain alat pemeras santan kelapa

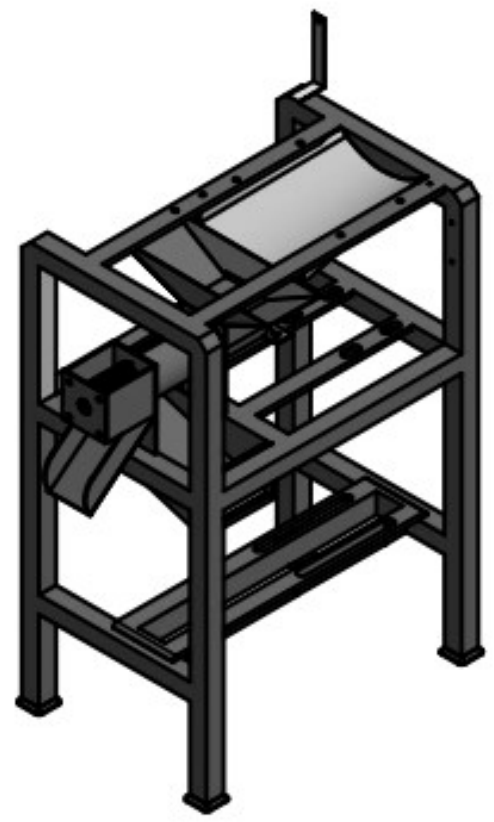

Gambar 2. Kerangka alat pemeras kelapa

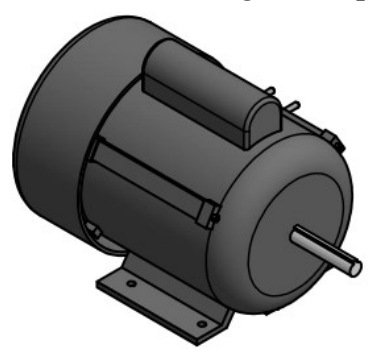

Gambar 3. Dinamo motor penggerak

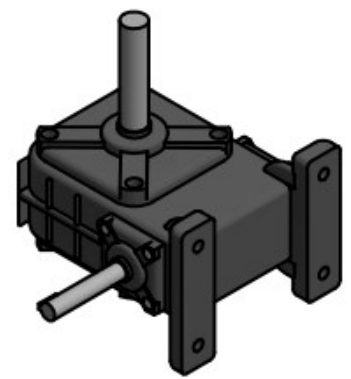

Gambar 4. Gear box

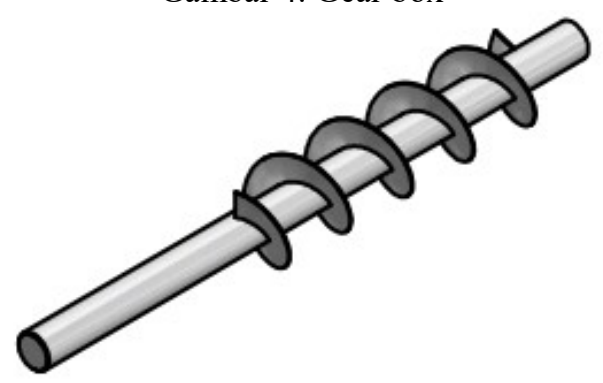

Gambar 5. Ulir pemeras kelapa

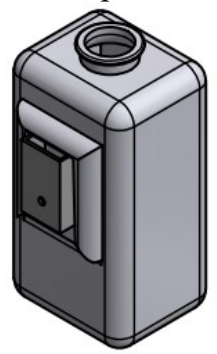

tempat

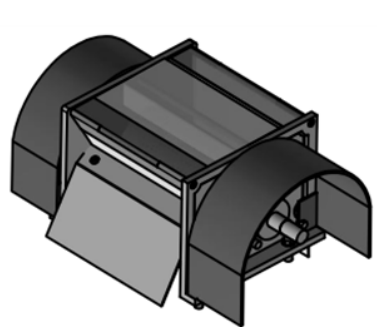

Gambar 6.

air

Gambar 7. Alat pemarut kelapa

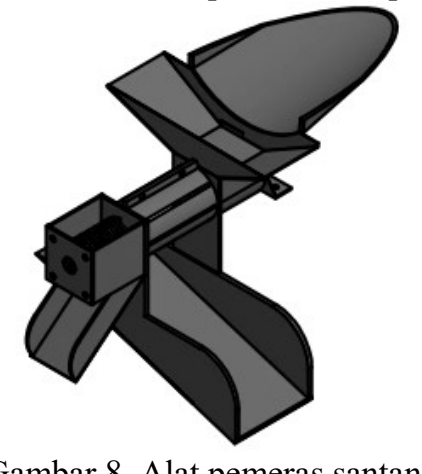

Gambar 8. Alat pemeras santan 


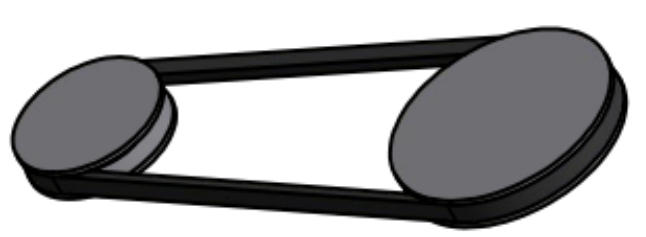

Gambar 9. V belt dan roda

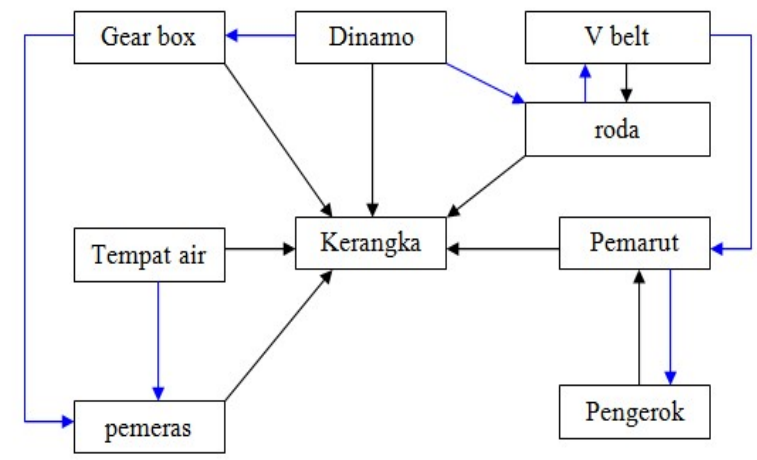

Gambar 11. Integrasi antar tiap komponen

Keterangan :

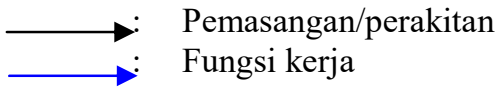

Tabel 1. Hasil rekapitulasi persentil

\begin{tabular}{|l|l|l|l|l|l|}
\hline No & $\begin{array}{l}\text { Data yang } \\
\text { di ukur }\end{array}$ & $\begin{array}{l}\text { Sim } \\
\text { bol }\end{array}$ & $\begin{array}{l}\text { Perse } \\
\text { ntil } \\
5\end{array}$ & $\begin{array}{l}\text { Perse } \\
\text { ntil } \\
50\end{array}$ & $\begin{array}{l}\text { Perse } \\
\text { ntil } \\
95\end{array}$ \\
\hline 1 & $\begin{array}{l}\text { Tinggi siku } \\
\text { berdiri }\end{array}$ & Tsb & 97,93 & 105 & $\begin{array}{l}112, \\
07\end{array}$ \\
\hline 2 & $\begin{array}{l}\text { Jangkauan } \\
\text { tangan ke } \\
\text { depan }\end{array}$ & Jtd & 68,09 & 74 & $\begin{array}{l}79,9 \\
7\end{array}$ \\
\hline
\end{tabular}

Tabel 2. Pemenuhan Kebutuhan Pelanggan

\begin{tabular}{|c|c|}
\hline Customer Need & Solusi \\
\hline 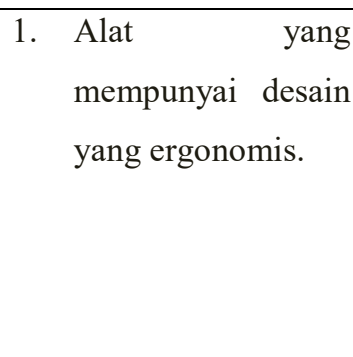 & $\begin{array}{lr}\text { 1. } & \text { Perancangan } \\
\text { dengan data } \\
\text { Tinggi } \\
\text { berdiri siku } \\
\text { Jangkauan } & \text { dangan } \\
\text { kedepan } & \end{array}$ \\
\hline $\begin{array}{l}\text { 2. Alat yang } \\
\text { dikembangkan } \\
\text { sistemnya secara } \\
\text { otomatisasi tidak } \\
\text { secara manual. }\end{array}$ & $\begin{array}{l}\text { 2. Alat mempunyai } \\
\text { fungsi lebih dari } \\
\text { satu dan dengan } \\
\text { satu penggerak } \\
\text { yang terhubung }\end{array}$ \\
\hline
\end{tabular}

3. Alat pemarutnya sekaligus sebagai pemeras jadi lebih efektif dan efisien.

4. Alat menggunakan bahan yang higienis dan steril.

5. Alat mudah dalam pengoperasiannya dan perawatannya.

6. Alat dapat melakukan proses pemarutan dan pemerasan dengan cepat.

7. Alat yang hemat listrik atau bahan bakar.

8. Alat yang bisa secara otomatis memisahkan antara santan kelapa dan ampas.

9. Alat yang bisa mengahasilkan parutan dan santan dengan kualitas yang baik.

10. Alat yang dapat melakukan dengan semua fungsi.

3. Dibuat satu line jadi setelah diparut langsung mengalir ke pemeras.

4. Bahan pemarut dan pemeras dibuat dari bahan stainless steel

5. Sekali on langsung pakai dan beberapa bagian bisa dilepas untuk memudahkan untuk dibersihkan.

6. Motor yang dipakai mempunyai kecepatan tinggi dan bisa diatur dengan gear box.

7. Dinamo mempunyai watt yang rendah.

8. Sistem pemeras dilengkapi ulir dan per.

9. Sistem dilengkapi ulir dan per.

10. Dengan sistem yang mengalir dengan baik akan 


\begin{tabular}{|l|l|}
\hline $\begin{array}{l}\text { pengoperasian } \\
\text { dengan kapasitas }\end{array}$ & meningkatkan \\
yang besar. & pemakitas \\
& \\
\hline
\end{tabular}

\begin{tabular}{|l|l|l|}
\hline 15 & Rumah Scruw & Rumah scruw D 25cm \\
\hline 16 & $\begin{array}{l}\text { Rangka } \\
\text { dudukkan }\end{array}$ & $\begin{array}{l}\text { V-belt, Tipe A -35 (bawah), } \\
\text { Tipe A-37 (atas) }\end{array}$ \\
\hline 17 & $\begin{array}{l}\text { Dudukan AS } \\
\text { mesin pemeras }\end{array}$ & UCFL 206 \\
\hline
\end{tabular}

Tabel 3. Spesifikasi produk

\begin{tabular}{|c|c|c|}
\hline No & Spesifikasi & Keterangan \\
\hline 1 & Dimensi & $60 \times 45 \times 110 \mathrm{~cm}$ \\
\hline 2 & Rangka alat & Kanal U,Plat strif \\
\hline 3 & Ulir & $\begin{array}{l}\text { D 10Ulir D 22mm, Panjang } 25 \\
\mathrm{~cm} \text {, Pitch } 1,5 \mathrm{~cm} \text { thickness } 3 \mathrm{~mm}\end{array}$ \\
\hline 4 & Bearing & $5 \mathrm{~cm}$ \\
\hline 5 & Motor listrik & JY1A-4 220 Volt \\
\hline 6 & Gear box & Tubemill gear box \\
\hline 7 & Pully & Tipe B \\
\hline 8 & $\mathrm{~V}$ belt & B-33 \\
\hline 9 & Gear & $7 \mathrm{~cm}$ \\
\hline 10 & Parutan & $\begin{array}{l}\text { Diameter lingkaran } 100 \mathrm{~mm} \text {, } \\
\text { panjang } 200 \mathrm{~mm}\end{array}$ \\
\hline 11 & Kopling & $\begin{array}{l}\text { Type B68, In } \varnothing 22 \mathrm{~mm} \text {, out } \varnothing \\
25,4 \mathrm{~mm}\end{array}$ \\
\hline 12 & Per & $\varnothing 3 \mathrm{~mm}$, panjang $100 \mathrm{~mm}$ \\
\hline 13 & Pully transfer & Pully transfer diameter D13cm \\
\hline 14 & $\begin{array}{l}\text { Batang AS } \\
\text { pemarut }\end{array}$ & AS pemarut $\mathrm{D} 2 \mathrm{~cm}$ \\
\hline
\end{tabular}

